九州大学学術情報リポジトリ

Kyushu University Institutional Repository

\title{
Fermentation of Cellulose by a Newly Isolated Thermophilic Clostridium sp.
}

Hayashida, Shinsaku

Laboratory of Applied Microbiology, Faculty of Agriculture, Kyushu University

Ahn, Byoung-Kwon

Laboratory of Applied Microbiology, Faculty of Agriculture, Kyushu University

Yoshino, Sadazo

Laboratory of Applied Microbiology, Faculty of Agriculture, Kyushu University

Ogata, Se iya

Laboratory of Applied Microbiology, Faculty of Agriculture, Kyushu University

https://doi.org/10.5109/23763

出版情報: 九州大学大学院農学研究院紀要. 27 (3/4)，pp.99-107，1983-02. Kyushu University バージョン：

権利関係 : 
J. Fac. Agr., Kyushu Univ., 27 (3 • 4), 99-107 (1983)

\title{
Fermentation of Cellulose by a Newly Isolated Thermophilic Clostridium sp.
}

\section{Shinsaku Hayashida, Byoung-Kwon Ahn, Sadazo Yoshino and Seiya Ogata}

Laboratory of Applied Microbiology, Faculty of Agriculture, Kyushu University 46-02, Fukuoka 812

(Received July 20, 1982)

\begin{abstract}
A thermophilic, cellulolytic, gram negative, terminally sporulating and anaerobic bacterium was isolated from compost heap. Its colonies on solid medium containing cellulose were irregular, clear, translucent and had an undulated margin. The cells grown on the solid medium were rods of 0.5 to $0.7 \mu \mathrm{m}$ wide by 3 to $6 \mu \mathrm{m}$ long. All the properties insisted that this bacterium belonged to the genus Clostridium. Its optimum growth temperature was $60^{\circ} \mathrm{C}$. This bacterium produced ethanol (45 mM), n-butanol (20 mM), acetic acid (23 $\mathrm{mM})$ and $\mathrm{n}$-butyric acid (25 $\mathrm{mM}$ ) during $150 \mathrm{hr}$ cultivation in a liquid medium containing $1 \%$ cellulose as a sole carbohydrate source. The characteristic of n-butanol production may be a rare case in thermophilic cellulolytic anaerobes.
\end{abstract}

\section{INTRODUCTION}

First cellulolytic anaerobes were isolated from rumen of herbivorous animals. Most of them belonged to mesophilic Clostridium species, and their products were ethanol, acetic acid, butyric acid, lactic acid, formic acid and etc. (Hungate, 1960). Their cellulase activities were weak. Thermophilic anaerobes have also been studied by several workers (McBee, 1948; Lee and Blackburn, 1975; Weimer and Zeikus, 1977), because their degradation ability toward cellulose was stronger than that of mesophilic anaerobes.

In this work, we investigate on a newly isolated thermophilic cellulolytic anaerobe, especially its properties of solvent production.

\section{MATERIALS AND METHODS}

\section{Media}

The basal medium had the following composition per liter of deionized water: solution A (per $700 \mathrm{ml}$ ); $\mathrm{K}_{2} \mathrm{HPO}_{4}, 2.2 \mathrm{~g} ; \mathrm{KH}_{2} \mathrm{PO}_{4}, 1.5 \mathrm{~g} ;\left(\mathrm{NH}_{4}\right)_{2} \mathrm{SO}_{4}, 1.3 \mathrm{~g} ; \mathrm{FeSO}_{4}$. $7 \mathrm{H}_{2} \mathrm{O}, 6 \mathrm{mg} ; \mathrm{Na}_{2} \mathrm{CO}_{3} \cdot 10 \mathrm{H}_{2} \mathrm{O}, 4 \mathrm{~g} ;$ yeast extract, $2 \mathrm{~g}$; polypepton, $5 \mathrm{~g} ; \mathrm{CaCO}_{3}, 5 \mathrm{~g}$ (only for liquid medium) and solution $\mathrm{B}$ (per $300 \mathrm{ml}$ ): $\mathrm{MgCl}_{2} \cdot 6 \mathrm{H}_{2} \mathrm{O}, 1 \mathrm{~g} ; \mathrm{CaCl}_{2}$, $0.15 \mathrm{~g}$; cystein $\mathrm{HCl} \cdot \mathrm{H}_{2} \mathrm{O}, 0.5 \mathrm{~g}$. The $\mathrm{pH}$ of each solution was adjusted to 7.0. Solutions A and B were separately sterilized at $1.2 \mathrm{~kg} / \mathrm{cm}^{2}$ for $20 \mathrm{~min}$, and mixed aseptically just before use. Enriched liquid medium contained $5 \mathrm{~g}$ of Avicel (microcrystalline cellulose, Asahi Chemical Industry Ltd.) and $10 \mathrm{~g}$ of filter 
paper (Toyo Roshi Co. Ltd.) per liter of the basal medium contained $10 \mathrm{~g}$ of Avicel and $20 \mathrm{~g}$ of agar per liter of the medium. Fermentation test medium contained $5 \mathrm{~g}$ of various carbohydrates per liter of the basal medium. A larger scale liquid medium for the analysis of products contained $10 \mathrm{~g}$ of Avicel per liter of the basal medium.

\section{Isolation of thenuophilic cellulolytic anaerobe}

A thermophilic cellulolytic anaerobe was isolated from compost heap of the mixture of horse dung, rice strows and grass, collected from the Kasuya area of Fukuoka Prefecture.

One $\mathrm{g}$ of compost heap was suspended in $10 \mathrm{ml}$ of $0.15 \mathrm{M} \mathrm{NaCl}$ solution. Then, $1 \mathrm{ml}$ of the suspension was inoculated in $10 \mathrm{ml}$ of enriched liquid medium containing $0.5 \%$ Avicel and $1 \%$ filter paper, and cultivated at $60^{\circ} \mathrm{C}$. After 7 days, the filter paper-digested culture was inoculated in the fresh enriched liquid medium and cultivated as same above. After following 7 days, the filter paper-digested culture was diluted serially and each dilution was inoculated into solid medium of roll tube, according to Hungate (1944). Cellulose digesting colonies appeared on solid medium were picked up and their purity was certified by following the criteria of Hungate (1960). The isolates were preserved at $-20^{\circ} \mathrm{C}$ in the culture medium plus $1 \%$ glycerine.

Anaerobic condition was maintained by passage of stream of $\mathrm{N}_{2}$ gas. All anaerobic vessels were sealed with rubber stoppers.

\section{Determination of cell growth}

In liquid medium containing cellulose, cell growth was followed by measuring the contents of cell protein (Herbert et al., 1971), because the turbidity was not proportional to cell growth due to the existence of cellulose fibers. An aliquot of culture broth was taken out at desired intervals and centrifuged at $8,000 \times g$ for $20 \mathrm{~min}$. The precipitate was washed with $0.15 \mathrm{M} \mathrm{NaCl}$ solution, and the cells in the precipitate were'hydrolysed with $1 \mathrm{~N} \mathrm{NaOH}$ at $100^{\circ} \mathrm{C}$ for 5 min. Protein content in the hydrolysate was measured by the methods of Lowry et al. (1951).

In liquid media containing soluble carbohydrates, cell growth was followed by measuring the turbidity $\left(\mathrm{OD}_{660}\right)$ using electric photometer (Tokyo Koden Co. Ltd., Type 8 A).

\section{Analysis of products}

A $250 \mathrm{ml}$ of liquid medium containing $1 \%$ Avicel was used for the analysis of products. At desired time intervals, an aliquot of culture broth was taken out and centrifuged at $8,000 \mathrm{xg}$ for $20 \mathrm{~min}$. Its supernatant was subjected to the following analysis. The supernatant was applied on a small column $(1 \mathrm{ml}$ of volume) packed with Dowex $50 \mathrm{~W}$ X2 (100-200 mesh). The filtrate was analysed on the gas-chromatography (Hitachi Ltd., Type 163) which was equipped with glass $\mathrm{U}$ column $(3 \mathrm{~mm} \times 2 \mathrm{~m}$ ) packed with chromosorb $10 \mathrm{i}$ (Ottenstein and Bartley, 1971; Carlson, 1972). Amount of solvents and $\mathrm{C}_{2}-\mathrm{C}_{5}$ organic acids were calculated from their peak heights.

Products fermented from various carbohydrates were also analysed by gas. 
chromatography, as described above.

\section{Analysis of cellulase activities}

Carboxymethylcellulase (CMCase : $\mathrm{C}_{\mathrm{x}}$ activity) was measured as follows. One of the supernatant of culture broth was added to $1 \mathrm{ml}$ of $1 \%$ sodium carboxymethyl cellulose in phosphate buffer $(0.1 \mathrm{M}, \mathrm{pH} 6.5)$ and incubated at $60^{\circ} \mathrm{C}$ for $5 \mathrm{hr}$, agitated by Monod shaker at 50rpm. The amount of reducing sugars liberated in the mixture was measured by the method of Somogyi (1952) and reading was taken at $\mathrm{OD}_{500 \mathrm{~nm}}$ using by spectrophotometer (Hitachi Ltd., Type 124). Avicelase activity ( $C$, activity) was measured by the same method as CMCase activity, using Avicel as substrate instead of CMC.

\section{Analysis of residual cellulose}

An aliquot of culture broth was centrifuged and the precipitate was hydrolysed, as described above. And then, a desired volume of conc. acetic acid was added to the precipitate in order to dissolve residual $\mathrm{CaCO}_{3}$. The residual cellulose in the suspension was filtrated by $5 \mu \mathrm{m}$ of pore size of membrane filter (Toyo Roshi Co., Ltd.). The filtrated cellulose was dried at $60^{\circ} \mathrm{C}$ for 12 hr, and weighed (Herbert et al., 1971).

\section{Electron microscopy}

A 5 day-old culture grown on solid medium containing $1 \%$ Avicel was used for electron microscopy. The cells were stained with $2 \%$ phosphotungstic acid solution, and observed with JEM $100 \mathrm{~B}$ electron microscope (Japan Electron Optics Lab. Ltd :.

\section{RESULT}

\section{Morphology of colony and cells of strain $\mathrm{AH}-1$}

A thermophilic and cellulolytic anaerobe isolated from compost heap was named as strain AH-1. Strain AH- 1 made clear cellulolytic zone around the colonies on solid medium containing 1\% Avicel, as shown in Fig. 1. The colonies and their cellulolytic zone were $1 \mathrm{~mm}$ and $2 \mathrm{~mm}$ in diameter, respectively. They were translucent, white color and irregular form with undulated margin. Under microscopic observation, the cells were straight or slightly curved rod, slightly motile and formed oval terminal endospore. Its size was 0.5 to 0.7 $\mu \mathrm{m}$ wide by 3 to $5 \mu \mathrm{m}$ long. The cells were stained gram negatively.

\section{Growth condition of strain $\mathrm{AH}-1$}

Strain AH-1 grew at high temperature, the range from 50 to $65^{\circ} \mathrm{C}$, and no growth was observed below $45^{\circ} \mathrm{C}$ or above $70^{\circ} \mathrm{C}$, as shown in Fig. 2. Highest growth was observed at $60^{\circ} \mathrm{C}$. After $10 \mathrm{hr}$ of lag phase, exponential growth phase continued for $20 \mathrm{hr}$ in liquid medium containing $1 \%$ Avicel at $60^{\circ} \mathrm{C}$. In stationary phase, the cell protein was $0.32 \mathrm{mg}$ per $\mathrm{ml}$ of culture broth at $60^{\circ} \mathrm{C}$. The optimum $\mathrm{pH}$ for growth was 6.5 to 7.0. No growth occurred aerobically

Determination of biochemical properties of strain AH--I 


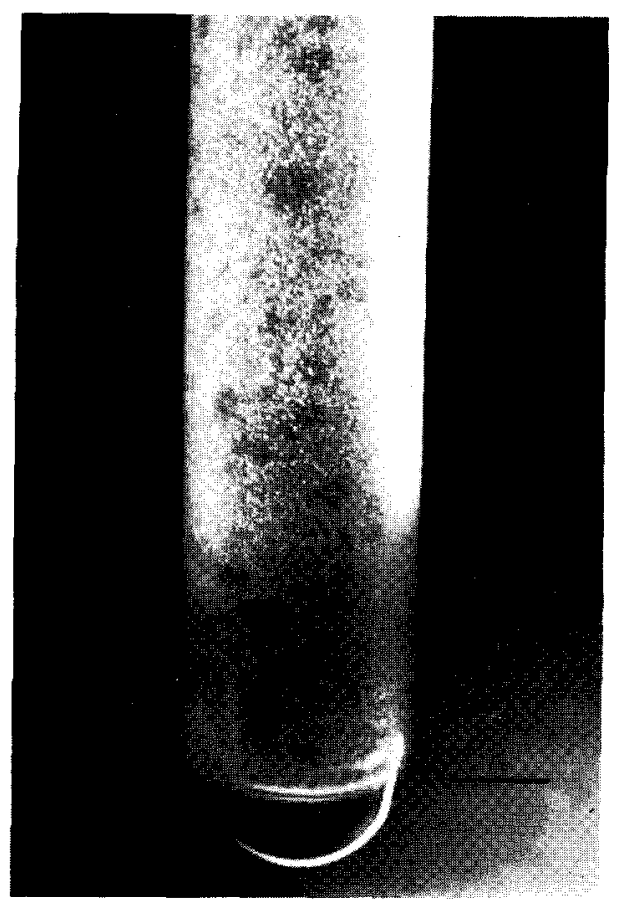

Fig. 1. Colonies of strain $\mathrm{AH}-\mathrm{-1}$ in role tube after 5 days of cultivation. Bar shows $1 \mathrm{~cm}$.

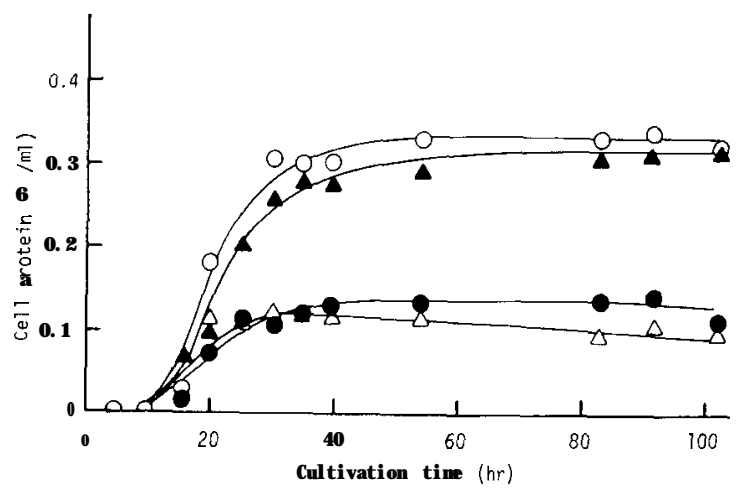

Fig. 2. Growth curve of strain $\mathrm{AH}-1$ at various temperature. Strain AH-1 was grown in a $250 \mathrm{ml}$ of liquid medium containing $1 \%$ Avicel. $\longrightarrow \triangle-, 50^{\circ} \mathrm{C} ;-\triangle-, 55^{\circ} \mathrm{C} ;-\circ-, 60^{\circ} \mathrm{C} ;-.-, 65^{\circ} \mathrm{C}$.

Biochemical properties of strain $\mathrm{AH}-1$ were investigated as followed by the methods of Suzuki (1968). As shown in Table 1, strain AH 1 did not utilize sodium sulfate added into the liquid medium, not liquify gelatin and not reduce sodium nitrate through 5 days cultivation at $60^{\circ} \mathrm{C}$. Strain $\mathrm{AH}-1$ produced 
Table 1. Properties of strain AH-1.

\begin{tabular}{ll}
\hline \multicolumn{2}{c}{ Tests } \\
\hline Sulfate reduction & \\
Gelatin liquification & - \\
Nitrate reduction & \\
Acetylmethylcarbinol production & - \\
Indol production & + \\
Urease production & - \\
Catalase production & \\
Gram staining & \\
\hline
\end{tabular}

indol as the result of utillization of tryptophane that contained in polypepton.

Utilization of various carbohydrates by strain AH-1

Strain AH-l fairly fermented fructose, galactose, glucose, mannose, cellobiose, lactose, maltose, sucrose, melibiose, trehalose, dextrin, glycogen, starch, amygdalin, esculin, salicin, dulcitol and solbitol, though the cultivation times reached to the stationary phase were varied each other. The growth hardly occurred without carbohydrates, as shown in Table 2.

As shown in Table 3, strain AH-l produced ethanol, n-butanol, acetic acid and n-butyric acid from all carbohydrates fermented in 5 day of cultivation.

Cellulolytic activities

In a $250 \mathrm{ml}$ of liquid culture containing $1 \%$ Avicel, the cellulose degradation continued over $150 \mathrm{hr}$ of cultivation, though the cell growth came to stationary phase at $50 \mathrm{th} \mathrm{hr}$. The cellulose was degraded to the extent of $80 \%$ at 150 th hr, as shown in Fig. 3. CMCase activity in the supernatant of the

Table 2. Utilization of carbohydrates by strain AH-1.

\begin{tabular}{|c|c|c|c|}
\hline Carbohydrates & Growth" & Carbohydrates & Growth" \\
\hline nosaccharide & & Polysaccharide & \\
\hline L-(+)-Arabinose & + & Dextrin & \# \\
\hline D- $(+)$-Fructose & H & Glycogen & 世 \\
\hline D- $(+)-G a l a c t o s e$ & H & Inulin & + \\
\hline D- $(+)-$ Glucose & \# & Starch & H \\
\hline$D-(+)-$ Mannose & \# & Glucoside & \\
\hline L-(+)-Rhamnose & + & Amygdalin & \# \\
\hline D- $(+)$-Ribose & + & Esculin & \# \\
\hline $\bar{D}-(+)-X y l o s e$ & + & Salicin & 州 \\
\hline Sorbose & + & Alcohol & \\
\hline Disaccharide & & Erythritol & - \\
\hline Cellobiose & itt & Inositol & \\
\hline Lactose & H & Mannitol & + \\
\hline Maltose & \# & Glycerol & - \\
\hline Sucrose & H & Dulcitol & H \\
\hline Melibiose & \# & Sorbitol & $\mathrm{ttt}$ \\
\hline Trisaccharide & & Adonitol & - \\
\hline Trehalose & \# & & \\
\hline Raffinose & $t$ & None & \\
\hline
\end{tabular}

1) Growth was determined by its tnrbidity $\left(O D_{660 \mathrm{~nm}}\right)$ when the culture reached to stationary phase. H, $>0.4 ; H, 0.2-0.4 ;+,\langle 0.2 ;-$, no growth. 
Table 3. Products of strain AH-1 in liquid culture containing various carbohydrates. Strain AH-1 was cultivated in $10 \mathrm{ml}$ of fermentation test medium containing $0.5 \%$ each carbohydrate at $60^{\circ} \mathrm{C}$.

\begin{tabular}{|c|c|c|c|c|}
\hline \multirow{2}{*}{ Carbohydrates } & \multicolumn{4}{|c|}{ Products (mM) } \\
\hline & Ethanol & n-Butanol & Acetic acid & n-Butyric acid \\
\hline D-(+)-Fructose & 24.7 & 1.7 & & 10.7 \\
\hline D-(+)-Galactose & 28.2 & 2.5 & 14.57 .8 & 3.2 \\
\hline D-(+)-Glucose & 23.3 & $1: 5$ & 13.7 & 10.4 \\
\hline D- $(+)$--Mannose & 24.4 & 1.2 & & 11.3 \\
\hline L-(+)-Rhamnose & 5.9 & 2.8 & 1991219.6 & 18.0 \\
\hline D- $(+)$-Ribose & 12.7 & 3. 0 & & 6.4 \\
\hline D- $(+)-X y l o s e$ & 16.5 & 1.3 & 12.8 & 8.8 \\
\hline Cellobiose & 27.0 & 2.2 & 15.16 .4 & 14.8 \\
\hline Lactose & 25.3 & & & 21: 2 \\
\hline Maltose & 29.5 & 3.2 & 14.4 & 14.1 \\
\hline Sucrose & 47.1 & 1.9 & 8.2 & 2.8 \\
\hline Tre halose & 31.5 & 4.9 & 8.9 & 29.6 \\
\hline Dextrin & 28.5 & 2.6 & 11.4 & 12.8 \\
\hline Starch & 26.5 & $0,2.6$ & 11.8 & 10.8 \\
\hline None & trace & & trace & trace \\
\hline
\end{tabular}

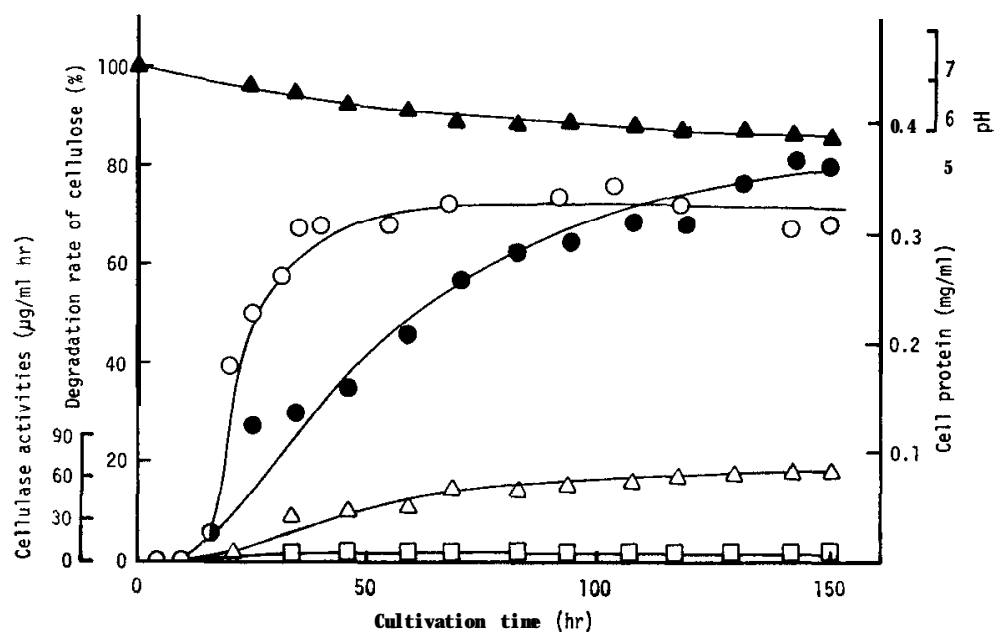

Fig. 3. Time-course of cellulose degradation and production of cellulose by strain AH-1 at $60^{\circ} \mathrm{C}$. Strain AH-1 was grown in a $250 \mathrm{ml}$ of liquid medium containing $1 \%$ Avicel. —०-, cell growth; - - - degradation rate of cellulose; $\longrightarrow \mathbf{\Delta -}$. CMCase activity; - $\square-$, Avicelase activity; $\rightarrow-\mathrm{pH}$.

culture broth increased proportionally with the cellulose degradation rate. Its activity was $64 \mu \mathrm{g}$ of glucose per $\mathrm{ml} \cdot \mathrm{hr}$ at $150 \mathrm{th} \mathrm{hr}$ of cultivation. Avicelase activity was one-tenth of CMCase activity and it did not increase through the cultivation. Avicelase of strain AI--l might be hardly released into the culture broth. 
Strain AI-1 produced ethanol, n-butanol, acetic acid and n-butyric acid through the fermentation of cellulose. Ethanal and acetic acid were produced in the culture broth at the beginning of exponential growth phase, and gradually increased from early stationary phase to about $130 \mathrm{hr}$ of stationary phase. n-Butyric acid and n-butanol were detected at early stationary phase, and increased until $130 \mathrm{hr}$ of stationary phase, as shown in Fig. 4 . At 150th hr of cultivation, the yields of products were as follows ; ethanol $45 \mathrm{mM}(2.1 \mathrm{~g} / \mathrm{l}), n$ butanol $20 \mathrm{mM}(1.5 \mathrm{~g} / \mathrm{l})$, acetic acid $23 \mathrm{mM}(1.4 \mathrm{~g} / \mathrm{l})$ and n-butyric acid $25 \mathrm{mM}$ (2.2 $\mathrm{g} / 1)$.

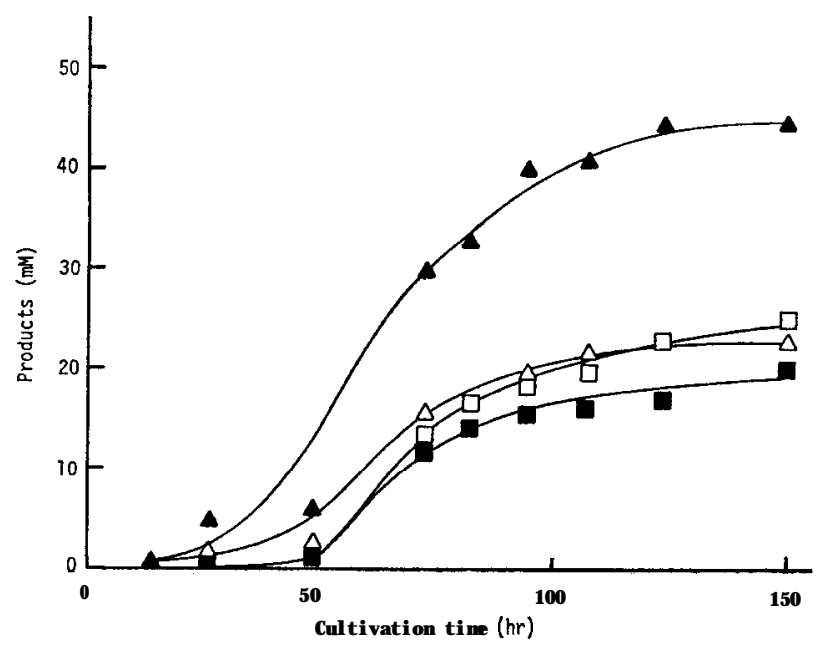

Fig. 4. Production of solvents and organic acids during cellulose fermentation by strain AH-1. Strain AH-1 was grown in a $250 \mathrm{ml}$ of liquid medium containing 1 \% Avicel. $\longrightarrow-$, ethanol; $\longrightarrow-$ - n-butanol; $\longrightarrow-$, acetic acid ; - $\square-$, n-butyric acid.

\section{DISCUSSION}

A newly isolated thermophilic cellulolytic anaerobe, strain AH-l, was motile and spore forming rod, and this strain could not utilize sulfate. These properties implied that strain AI-1 belonged to genus Clostridium, not to Desulfotomaculum (Smith and Hobbs, 1974), compared with some thermophilic and cellulolytic clostridia already reported. Furthermore strain AH-l have similar morphological and biochemical properties, but differs in the utilization of carbohydrates and their products. C. thermocellum (McBee, 1948; Weimer and Zeikus, 1977; Taya et al., 1978) cannot grow in the absence of special substrate, cellulose, hemicellulose or their components such as xylose and cellobiose. Its products are formic acid, acetic acid, lactic acid and ethanol, but n-butyric acid and n-butanol are not detected (McBee, 1948). Whereas strain AH-l can grow even in non-cellulosic carbohydrates such as fructose, lactose, glycogen and starch. And it produced ethanol, n-butanol, acetic acid and n-butyric acid from 
those carbohydrates utilized. These properties and its biological properties that strain AH-1 is different species from C. thermocellum that belong to group indicate $\mathrm{V}$ of genus Clostridium. And strain AH-l belong to group III, though no thermophilic Clostridium is described in Bergey's manual (Smith and Hobbs, 1974). On the other hand, C. thermocellulaseum (Enebo, 1951) and Clostridium sp. M7 (Lee and Blackburn, 1975) are thought to be similar species as those strains have wide variety of fermentative capacity. But the former do not produce n-butanol, and the latter is not investigated on its productivity of acids and solvents.

Strain AH-l degraded 8g of cellulose per liter of culture broth in $150 \mathrm{hr}$ of cultivation. But its Avicelase activity was weak compared with CMCase activity. This weak Avicelase activity might be caused by the adsorption of Avicelase to undegraded cellulose or cell-boundary properties of the cellulases as described in the previous reports (Lee and Blackburn, 1975; Ng et al., 1977).

The products of strain AH-1 from cellulose were ethanol, n-butanol, acetic acid and n-butyric acid. They are typical products of non-cellulolytic and mesophilic clostridia. In the case of thermophilic clostridia, n-butanol was hardly produced except for C. thermobutyricum (Enebo, 1951), but this strain cannot utilize cellulose as carbon source and its amount is very low compared with strain AH-1. Therefore, strain AH-1 is a unique thermophilic cellulolytic Clostridium, because of utilization of cellulose as substrate for n-butanol production.

In this work, we find out the possibility of solvent production using by thermophilic cellulolytic Clostridium. But the solvent productivity of strain AH-1 is fairly low compared with that of mesophilic clostridia. Our current studies are aimed at solving this problem,

\section{REFERENCES}

Carlson, J. 1972 Simplified gas chromatographic procedure for identification of bacterial metabolic products. Appl. Microbiol., 25: 287-289

Enebo, L. 1951 On the three bacteria connected with thermophilic cellulose fermentation. Phys. Plantmum, 4: 652-666

Herbert, D.. P. J. Phipps and R. E. Strange 1971 Chemical analysis of microbial cells. In "Methods in Microbiology", Vol. 5 B, ed. by J. R. Norris and D. W. Ribbons, Academic Press, London, pp. 209-344

Hungate, R. E. 1944 Studies on cellulose fermentation, the culture and physiology of anaerobic cellulose-digesting bacterium. J. Bactesiol, 48: 499-512

Hungate, R. E. 1960 The anaerobic mesophilic cellulolytic bacteria. Bacteriol. Rev., 14: 149

Lee, B. H. and T. H. Blackburn 1975 Cellulase production by a thermophilic Clostridium species. Appl. Microbiol., 30: 346-353

Lowry, 0. H., N. J. Rosebrough, A. L. Farr and R. J. Randall 1951, Protein measurement with the folin phenol reagent. J. Biol. Chem., 193: 265-275

McBee, R. H. 1948 The culture and physiology of a thermophilic cellulose fermenting bacterium. J.Bacteriol., 56: 653-663

Ng, T. K., P. J. Weimer and J. G. Zeikus 1977 Cellulolytic and physiological properties of Clostridium thermocellum. A rch. Microbiol., 114: 1-7 
Ottenstein, D. M. and D. A. Bartley 1971 Separation of free acids $\mathrm{C}_{2}-\mathrm{C}_{5}$ in dilute aqueous solution column technology. J. Chromatog. Sci., 9: 673-681

Smith, L. D. and G. Hobbs 1974 Part 15, Endospore-forming rods and cocci, Genus III, Clostridium. In "Bergey's Manual of Determinative Bacteriology", 8th ed., ed. by R. E. Buchanan and N. E. Gibbons, The Williams and Wilkins Company, Baltimore, pp. 551572

Somogyi, M. 1952 Notes on sugar determination. J.Biol.Chem., 195: 19-23

Suzuki, S. 1968 Identification methods. In "Anaerobes in Clinical Medicine", ed. by N. Kosakai and S. Suzuki, Igaku-shoin, Tokyo, pp. 67-82 (in Japanese)

Taya, M., Y. Ito, K. Ohmiya, T. Kobayashi and S. Shimizu 1978 Cellulose digestion with anaerobic microorganisms. Nokashi, 52: 567-574 (in Japanese)

Weimer, P. J. and J. G. Zeikus 1977 Fermentation of cellulose and cellobiose by Clostridium thermocellum in the absence and presence of Methanobacterium thermoautotrophicum. Appl. Environ. M icrobial., 33 : 289-297 